\title{
On the Use of Iron Chloride and Starch for Clarification in Drinking Water Treatment
}

\author{
Gomes CEP, Oliveira HA, Azevedo AC, and Jorge Rubio* \\ Laboratório de Tecnologia Mineral e Ambiental (LTM), Departamento de Engenharia de Minas, PPGE3M, Universidade Federal do Rio Grande do Sul, Avenida \\ Bento Gonçalves 9500, Brazil
}

*Corresponding author: Jorge Rubio, Laboratório de Tecnologia Mineral e Ambiental (LTM), Departamento de Engenharia de Minas, PPGE3M, Universidade Federal do Rio Grande do Sul; Avenida Bento Gonçalves 9500, 91501-970-Porto Alegre, Brazil, Tel: +55 51 3308-7879; E-mail: jrubio@ufrgs.br

Received: 28 May, 2021 | Accepted: 17 Jun, 2021 | Published: 24 Jun, 2021

Citation: Gomes CEP, Oliveira HA, Azevedo AC, Rubio J (2021) On the Use of Iron Chloride and Starch for Clarification in Drinking Water Treatment. Int J Water Wastewater Treat 7(1): dx.doi.org/10.16966/2381-5299.178

Copyright: @ 2021 Gomes CEP, et al. This is an open-access article distributed under the terms of the Creative Commons Attribution License, which permits unrestricted use, distribution, and reproduction in any medium, provided the original author and source are credited.

\begin{abstract}
In drinking water treatment plants, chemical reagents are employed to aggregate and remove suspended particles. However, not all reagents are eco-friendly and exists concerns over environmental, economic, and health issues. This study shows features of the sustainability of commercial coagulants/flocculants and presents experimental research on floc characterization and settling of dispersed solids with a combination of Ferric Chloride $\left(\mathrm{FeCl}_{3}\right)$ and gelatinized starch. Bench studies were conducted using kaolin suspensions and results were validated with raw water collected from a river (Rio dos Sinos, Brazil). Flocculation indexes, floc structure, and residual turbidities were compared with Polyaluminum Chloride (PAC), as a reference. All techniques showed that the combination of $\mathrm{FeCl}_{3}$ and starch formed well-structured, larger, and more settleable flocs than those produced with PAC. Superficial loadings, in a continuous separation tank ( 2 to $4 \mathrm{~m}^{-\mathrm{h}^{-1}}$ ) were studied with and without lamellae. Best results were obtained with $15 \mathrm{mg} \cdot \mathrm{L}^{-1} \mathrm{Fe}^{3+}$ and $10 \mathrm{mg} \cdot \mathrm{L}^{-1}$ starch, with a velocity gradient, $\mathrm{G}$, of $60 \mathrm{~s}^{-1}$ in the slow mixing and with $60^{\circ}$ inclined lamellae spaced 1.3 $\mathrm{cm}$ apart. Best conditions were applied to the clarification of the raw water and again, due to the rapid settling of flocs with $\mathrm{FeCl}_{3}$ and starch, better results were obtained compared to PAC. A turbidity reduction of $94 \%$ and a residual value of 2.5 NTU with superficial loadings of 3 m.h. $\mathrm{h}^{-1}$ were obtained. Results were discussed in terms of interfacial and operating parameters and a promising potential for the combination of $\mathrm{FeCl}_{3}$ with starch for solid/liquid separation was envisaged.
\end{abstract}

Keywords: Drinking water treatment; Reagent sustainability; Coagulation-flocculation-settling; Iron chloride plus starch

\section{Introduction}

The effective removal of suspended solids (micro and nanoparticles) is fundamental in drinking water treatment, reducing turbidity, odor, color, and organic matter from raw water. Thus, the efficient aggregation (coagulation and/or flocculation) and settling (or flotation) of the dispersed particles is key and attention has to be drawn to the selection of a suitable and sustainable destabilizing reagent [1-3].

According to BCC Research (2020), the global market of reagents for water and wastewater treatment will grow to more than $\$ 111$ billion by 2024, at a Compound Annual Growth Rate (CAGR) of $3.2 \%$. Yet, because this market includes reagents that might cause some environmental and public health problems, there is a general trend in the search (and research) for eco-friendly coagulants or flocculants that reduce these risks $[1,2]$.

The most common coagulant reagents employed in drinking water treatment plants are those based on aluminum, such as Aluminum Sulfate $\left(\mathrm{Al}_{2}(\mathrm{SO})_{4}\right)$ and Polyaluminum Chloride (PAC). Also, Polyacrylamides are occasionally used (at least in Brazil), when the waters are very turbid, as ancillary aggregation reagents assisting the coagulants to improve particle settling velocity [3-5]. Further, tanninbased destabilizing reagents, mostly produced from tree tissues (leaves, wood, or bark), have also been employed in drinking water and industrial effluent treatment units. These compounds adsorb onto the particles surfaces by a combination of electrostatic attraction, hydrogen bonding, and/or polymeric bridges, which depend on their charge density, molecular weight, and branching [6-8].

\section{Environmental considerations}

There is a major concern in the international scientific community about the safety of some of these reagents, especially those containing aluminum. There has been an ongoing discussion on the relationship between this metallic element (even at low concentrations) and neurodegenerative diseases [9-12].

In most countries, emission standards have been established for the total aluminum $\left(\mathrm{Al}^{3+}\right.$ and $\left.\mathrm{Al}(\mathrm{OH})_{3}\right)$ in treated water. Thus, the World Health Organization recommendation is $0.2 \mathrm{mg} \cdot \mathrm{L}^{-1}[13,14]$ as in Brazil (Ministry of Health, 2017) and Germany [15]. In the USA values vary between 0.05 and $0.4 \mathrm{mg} \cdot \mathrm{L}^{-1}$, depending on the state 
[12], while in Canada, the standards vary between 0.1 and $0.2 \mathrm{mg} . \mathrm{L}^{-1}$ [16]. These levels are general references and there is a worldwide consensus towards reducing these values to decrease the total intake of this metal [11].

Healthy individuals readily eliminate the residual aluminum present in treated water whereas elderly people with liver and kidney problems might accumulate it $[9-12,16]$. This situation may be aggravated considering daily higher exposure to this element via food, antacids, and cosmetics.

Regarding synthetic polymer flocculants, these chemicals usually release residual monomers, formed during polymerization synthesis. These compounds are remarkably toxic to humans, animals, and aquatic organisms $[17,18]$.

Moreover, the manufacturers of polyacrylamides are reluctant to divulge the exact chemical composition of their products. Despite that, it is known all are based on acrylamide chemistry and might present risks due to the toxicity of the by-products through polymerization reactions, notably acrylamide. Thus, degradation and transfer of the monomers to either surface or underground water courses is also a problem for aquatic species $[17,18]$.

In Brazil, the acrylamide limit in drinking water is $0.5 \mu \mathrm{g} . \mathrm{L}^{-1}$ as regulated by the Ministry of Health (Portaria de Consolidação MS 05/2017, Annex XX). The European Union has set a more restrictive parametric value for human tap water consumption at $0.10 \mu \mathrm{g} . \mathrm{L}^{-1}$ acrylamide [19]. According to the World Health Organization [13], values of about $0.5 \mu \mathrm{g} . \mathrm{L}^{-1}$ may serve as a guideline, but recommend that the exposure should be reduced to a level as low as technically achievable.

Tannin-based flocculants commercialized as organic and natural products in water treatment are modified natural tannins (predominantly from the bark of the tree Acacia mearnsii) with formaldehyde (classified as a category B1carcinogen) and ammonium chloride during the Mannich reaction $[8,20]$. As a result, the tannins are converted into a cationic form $[8,21,22]$. Recently, Machado G, et al. [8] studied the production of tannin-based flocculants without the need of using formaldehyde. The novel synthesis technique of a friendlier reagent appears to have good potential in terms of color and turbidity removal from simulated water.

To summarize, many international standards are starting to regulate the commercial products employed in water treatment, establishing sampling and analysis rules, as well as listing minimum health requirements. The focus is primarily on the associated chemical, either contaminants or impurities, which might end up in treated water [23]. Further, manufacturers should ensure the stability and sustainability of their commercial products by attending to these regulations and carrying out regular chemical analyses.

Alternatively, the development of eco-friendly coagulants/ flocculants is being studied, namely, applications involving natural starches and derivatives. Interestingly, gelatinized starches have been used heavily since the early $20^{\text {th }}$ century as flocculants in many industries, principally in mineral (iron ore) processing [24,25]. Lately, these reagents have been rediscovered for applications in effluent and water treatment [26-28].

The main advantages of natural-based flocculants, compared to the synthetics, include the availability of the raw material, the low levels of toxicity and corrosion, as well as the lower volume of sludge generated and biodegradability $[2,28,29]$.
Yet, some of the natural-based aggregation reagents, such as starch, chitosan, cellulose, guar gum, and dextran are modified and/ or incorporated (grafted) with many chemical compounds aimed at enhancing their coagulation/flocculation properties [2]. These modifications include copolymerization of the natural molecule with acrylamide, or other monomers, to generate grafted hybrid structures. Reactions with organic ammonium salts, mercaptans, sulfonic acids, carbamates, acrylates, among others, are conducted to modify their molecular weight, functional groups, and charge density characteristics. Again, concern and caution with respect to their chemical modifications should always be taken into account.

Examples of water and wastewater treatment studies using untreated starch-based flocculants are shown in table 1.

The main objective of this work was to evaluate the combination of ferric chloride and gelatinized natural starch an eco-friendlier alternative for drinking water treatment, especially when compared with the Polyaluminum Chloride (PAC). Herein, the flocculation index and the removal of dispersed solids from simulated water were fully studied. Best results were applied in real raw water in a continuous lab scale (Rio dos Sinos, Brazil) and the comparative effect of those reagents on the hydraulic superficial loading capacity was also studied.

\section{Experimental}

\section{Materials}

In the bench batch studies, Deionized (DI) water with $\mathrm{pH}=5.5$ and conductivity $<4 \mu \mathrm{S} . \mathrm{cm}^{-1}$ was employed with public water (Porto AlegreBrazil) in a continuous system. The simulated raw water was prepared with fine kaolin particles (D32 $=22 \mu \mathrm{m}, \mathrm{D} 10=3.5 \mu \mathrm{m}, \mathrm{D} 50=17.3 \mu \mathrm{m}$, D90 $=36.3 \mu \mathrm{m}$ ).

Polyaluminum Chloride (PAC Floc H120 HT-Ambientaly Ind., Brazil) and Ferric Chloride ( $\mathrm{FeCl}_{3} \cdot 6 \mathrm{H}_{2} \mathrm{O}$-Dinâmica Química, Brazil) were the coagulation reagents. Sodium hydroxide $(\mathrm{NaOH}-$ Dinâmica Química, Brazil) was used to adjust the $\mathrm{pH}$.

Commercial corn starch (Maizena ${ }^{\oplus}$, Unilever, Brazil) was used in the bench tests and high purity corn starch (Starch P.A.-Dinâmica Química, Brazil) in the continuous studies. The gelatinized starch was made from a mixture of $10 \mathrm{~g}$ starch and $1 \mathrm{~g} \mathrm{NaOH}$ in $1 \mathrm{~L}$ of DI water at $65^{\circ} \mathrm{C}$ until a homogenous gel was obtained.

The raw water was collected from the Rio dos Sinos at the COMUSA Water Treatment Plant (WTP) (Novo Hamburgo, Brazil) and had a turbidity of $26.2 \mathrm{NTU}$, electrical conductivity of $89 \mu{\mathrm{S} . \mathrm{cm}^{-1}}^{-1}$ and a $\mathrm{pH}$ of 6.5 .

\section{Methods}

Bench-scale studies: This stage aimed to optimize the physicalchemical and hydrodynamic parameters of aggregation: $\mathrm{pH}$, coagulant concentration, and velocity Gradients (G). A jar test (Nova Ética ${ }^{\star}$, model 218-3LDBF, Brazil) was employed and the tests were conducted with 120 s of rapid mixing $\left(\mathrm{G}=1000 \mathrm{~s}^{-1}\right)$ followed by 300 s of slow mixing $\left(\mathrm{G}=40 \mathrm{~s}^{-1}, 60 \mathrm{~s}^{-1}, 80 \mathrm{~s}^{-1}\right.$ and $\left.100 \mathrm{~s}^{-1}\right)$ and a separation time of $300 \mathrm{~s}$. The turbidity of the simulated raw water and treated water were measured in a bench turbidimeter $\left(\mathrm{HACH}^{\oplus}, 2100 \mathrm{~N}\right)$.

The coagulation-flocculation was studied under the following conditions: i) PAC (40-70 mg.L-1 $)$; ii) $\mathrm{FeCl} 3$ (5-20 mg L-1 of $\mathrm{Fe}^{3+}$ ) and gelatinized starch $\left(0-15 \mathrm{mg} . \mathrm{L}^{-1}\right)[30,31]$.

Herein, the ferric-based coagulant used was $\mathrm{FeCl}_{3}$ (Ferric Chloride) and the concentrations are expressed in mg. $\mathrm{L}^{-1}$ of ferric ion $\left(\mathrm{Fe}^{3+}\right)$. All these terms are used indistinctly throughout the text. 
Table 1: Main studies of untreated (non-modified) starches used in the treatment of water and effluents by coagulation-sedimentation.

\begin{tabular}{|c|c|c|c|}
\hline Reagents & Conditions & Main results & References \\
\hline $\mathrm{Al}_{2}\left(\mathrm{SO}_{4}\right)_{3}+$ cassava peel starch & $A M D$, acid mine drainage water treatment & $\begin{array}{l}89 \% \text { reduction in suspended solids and }>80 \% \\
\text { Escherichia coli }\end{array}$ & {$[30]$} \\
\hline $\mathrm{Al}_{2}\left(\mathrm{SO}_{4}\right)_{3}+$ gelatinized rice starch & Effluent of palm oil production treatment & $\begin{array}{l}\text { Reduction of } 88 \% \text { TSS, } 27 \% \text { COD, } 44 \% \text { total } \\
\text { phosphorous, and } 42 \% \text { total nitrogen }\end{array}$ & [31] \\
\hline $\mathrm{FeCl}_{3}$ and gelatinized corn starch & $\begin{array}{l}\text { Titanium dioxide nanoparticles }\left(\mathrm{TiO}_{2}-\mathrm{NPS}\right) \\
\text { removal by flocculation and settling or flotation }\end{array}$ & $\begin{array}{l}99 \% \mathrm{TiO}_{2}-\mathrm{NPs} \text { removal (residual concentration } \\
<30 \mathrm{mg} \cdot \mathrm{L}^{-1} \text { ) }\end{array}$ & {$[27]$} \\
\hline $\begin{array}{l}\mathrm{Al}_{2}\left(\mathrm{SO}_{4}\right)_{3}, \text { chitosan, sodium alginate, } \\
\text { potato starch }\end{array}$ & Supply water treatment & $74-80 \%$ color removal & {$[28]$} \\
\hline $\mathrm{FeCl}_{3}$ and gelatinized corn starch & Treatment of turbid surface water & 90 and $100 \%$ reduction in turbidity & [26] \\
\hline
\end{tabular}

In the experiments with $\mathrm{FeCl}_{3}$ plus starch, the ferric coagulant and the starch were added during a rapid mixing stage for $1 \mathrm{~min}$ and finally, the slow mixing was conducted for $5 \mathrm{~min}$. With PAC, the addition was done in two instances: the first dose (30-60 mg. $\left.\mathrm{L}^{-1}\right)$ during the rapid mixing stage and the second $\left(10 \mathrm{mg} \cdot \mathrm{L}^{-1}\right)$, added at the beginning of slow mixing, for floc growth.

Particle aggregation studies: The aggregation status of the suspended particles was measured in a photometric dispersion analyzer (Rank Brothers ${ }^{\circledR}$, Photometric Dispersion Analyzer-PDA 2000) described in figure 1 . This equipment uses a laser beam and an optical sensor that converts the transmitted light signal (related to the turbidity of the sample) and a floating signal (related to random variations in the number of particles) into an output Voltage (V) that indicates the sample's Flocculation Index (FI) $[6,32]$.

Evaluation of sludge volume and floc structure: A microscope (BEL Photonics ${ }^{\oplus}$, bulb $12 \mathrm{~V}$ 20W, WF10X) was used to capture microphotographs of the flocs formed (best aggregation condition). The sludge generated after $1 \mathrm{~h}$ was examined in an Imhoff cone (J Prolab $^{\star}$ ), following the standard methods for the examination of water and wastewater (2540 F-Settleable Solids) [33].

Continuous water treatment studies: The effect of the superficial hydraulic loading $\left(\mathrm{m} \cdot \mathrm{h}^{-1}\right)$ was evaluated using Conventional (SC) or Lamellar (SL) settling to remove the suspended solids from the treated simulated effluent. The continuous unit is described in figure 2 and the design (dimensional) parameters are shown in table 2.

The waters to be treated (kaolin suspension or raw water) were transferred to the separation unit with a peristaltic pump. The $\mathrm{pH}$ was adjusted with $\mathrm{NaOH}$ and the flocculants were added with dosing pumps (Exxata ${ }^{\circ}$ EX1) at the inlet of the flocculation chamber (rapid mixing).

The lamellae inserted in the settling tank are 32 acrylic plates (11.5 $\mathrm{cm} \times 7 \mathrm{~cm}$ ) spaced $1.3 \mathrm{~cm}$ apart and inclined at an angle of $60^{\circ}$ (best results). The residual turbidity (duplicates), were monitored in samples $(20 \mathrm{~mL})$ at $5 \mathrm{~min}$ intervals. The experiments were conducted after a stabilization time of $30 \mathrm{~min}$ (steady-state regime), equivalent to 2 residence times of the effluent during flocculation and sedimentation.

The continuous studies of kaolin/water separation by coagulationflocculation-settling were validated with raw water, collected from Rio dos Sinos, Brazil.

\section{Results and Discussion}

The main industrial application of starch is the reverse cationic flotation of gangue particles in mineral processing which act as a flocculant-depressant for the flotation of iron-bearing mineral particles. Here, the gelatinized starch flocculates the iron-bearing particles selectively, permitting the flotation of the siliceous gangue particles, with amines as a collector [24,34].

Authors explain that this selectivity is due to the chemical adsorption of the starch composite onto the iron-bearing species, mainly oxides and hydroxides [24,25]. The idea of using the combination of $\mathrm{FeCl}_{3}$ and gelatinized starch herein, a non-toxic coagulant-flocculant mixture, in water treatment, came from this industrial observation.

Studies to improve the flocculation ability of starches have followed different directions, namely: i) Gelatinization of the natural starches to free the amylose and amylopectin molecular fractions; ii) Modifying the starch structure chemically, mostly to convert them into cationic flocculants [2,34-36] and iii) Combining the starches with common coagulants, such as aluminum sulfate or ferric chloride. The last was the alternative studied in this work, following the viewpoint that the chemical modification of the starches must be well controlled and accepted by the environmental and sanitary agencies $[2,8]$.

\section{Bench studies}

Particle aggregation studies by photometric dispersion analysis: Figure 3 shows the flocculation index (FI values) of kaolin particle suspensions as a function of time, comparing values obtained with PAC (30-60 mg. $\left.\mathrm{L}^{-1}\right)$ to those with varying starch concentrations (5-15 mg. $\left.\mathrm{L}^{-1}\right)$ while keeping $\mathrm{Fe}^{3+}$ concentration constant at 10 mg. $\mathrm{L}^{-1}$. Results showed optimal values (FI on the order of 5) at $10 \mathrm{mg} . \mathrm{L}^{-1}$ of starch, and rapidly decreasing at lower and higher dosages. Contrarily, FI values with PAC were all very low and these results may be explained in terms of the larger and stronger flocs formed by the combination of ferric chloride and starch, compared with PAC (Figure 4).

Besides, Duan and Gregory (2003) reported that when using very high PAC dosages, the particles may become positively charged and that charge reversal could re-stabilize the particles, resulting in a loss of aggregation efficiency.

Characterization of flocs and settled solids: The microphotographs show that with $\mathrm{FeCl}_{3}$ and starch, flocs are more compact and denser than those formed by PAC (Figure 4). See other photographs in the Supplementary Data (Figure S1-S6).

Table 3 shows the results of the sludge volumetric concentrations in an Imhoff cone, comparing $\mathrm{Fe}^{3+}$ plus starch tothe flocs formed with PAC. Supplementary data (Figure S5) shows photographs of the Imhoff cone assays. After 5 min of slow mixing and 1 min of settling, the flocs formed with ferric coagulant and starch had a volumetric 


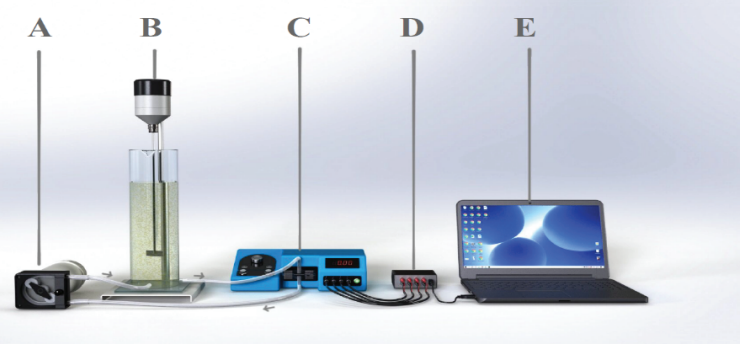

Figure 1: Schematic illustration of dispersion Photometric Analyzer (PDA). A) Peristaltic pump with a modular controller; B) $1 \mathrm{~L}$ cylindrical reactor with coupled mixer and $\mathrm{pH}$ probe; C) PDA reader; D) Data recorder; E) Notebook.

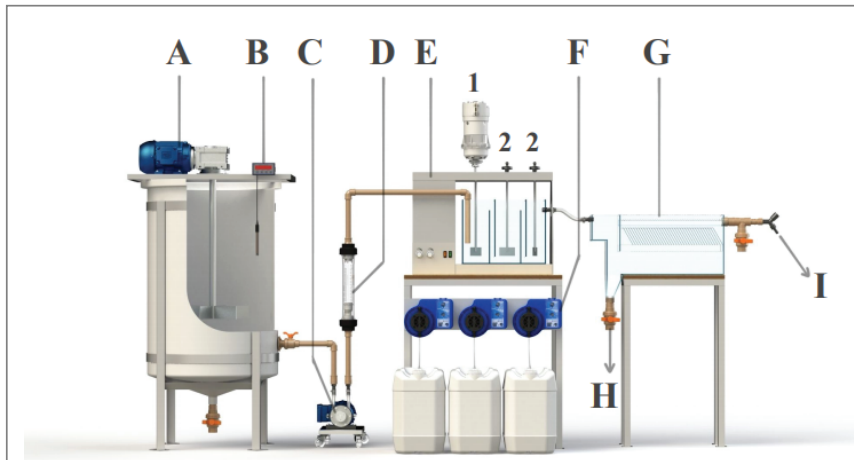

Figure 2: Continuous water treatment system by flocculation-settling: A: Feed water and coagulation tank; B: $\mathrm{pH}$ meter; C: Peristaltic pump; D: Flow meter; E: Flocculation units (1=Fast mixing, 2=Slow mixing); F: Dosing pumps; G: Separation (settling) unit; H: Sludge drain; I: Outlet of the treated water.

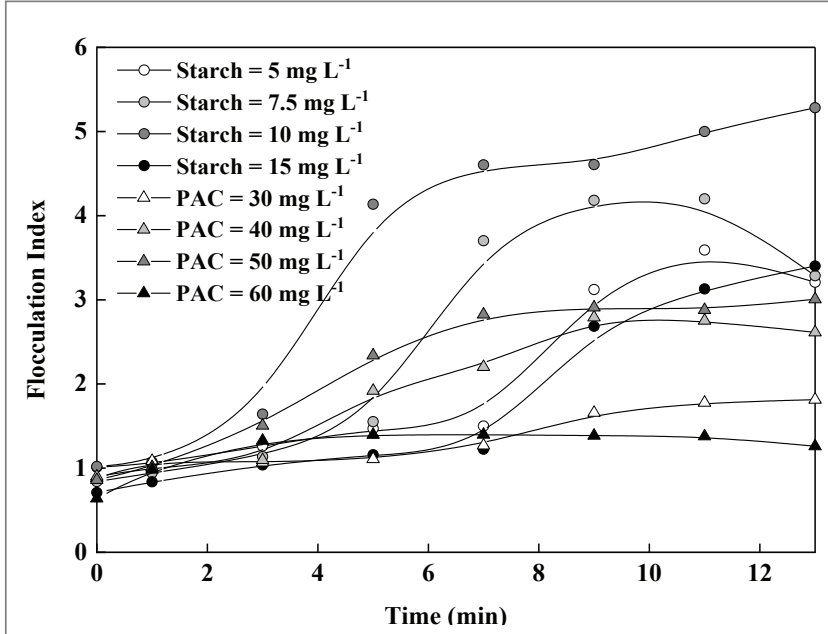

Figure 3: Flocculation index of aqueous kaolin suspensions as a function of time at various concentrations of starch or PAC. Conditions: $\left[\mathrm{Fe}^{3+}\right]=10 \mathrm{mg} \cdot \mathrm{L}^{-1}$ (for the experiments with starch); $\mathrm{pH}=7$; Feed turbidity $=45 \mathrm{NTU}$; [kaolin] $=0.13 \mathrm{~g} . \mathrm{L}^{-1} ; \mathrm{G}=40 \mathrm{~s}^{-1}$ (PAC) and $60 \mathrm{~s}^{-1}$ ( $\left.\mathrm{Fe}^{3+}+\mathrm{starch}\right)$.

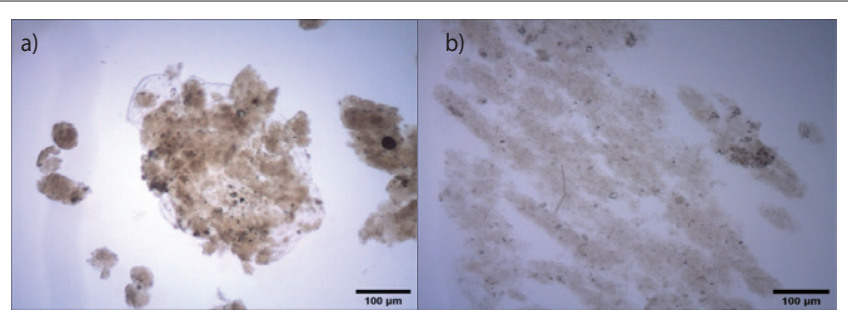

Figure 4: Microphotographs $(1280 \times 1024$ pixels $)$ of the flocs under two different conditions: a) $10 \mathrm{mg} . \mathrm{L}^{-1} \mathrm{Fe}^{3+}+10 \mathrm{mg} . \mathrm{L}^{-1}$ gelatinized starch, $\mathrm{pH}=7$ and $\mathrm{G}=60 \mathrm{~s}^{-1}(5 \mathrm{~min})$; b) $60 \mathrm{mg} \cdot \mathrm{L}^{-1} \mathrm{PAC}, \mathrm{pH}=7$ and $\mathrm{G}=40 \mathrm{~s}^{-1}$ (5 min).

Table 2: Design (dimension) parameters of the continuous effluent (water) treatment system. Physical dimensions: $\varnothing=$ diameter, $\mathrm{h}=\mathrm{height}$, W=width, L=length.

\begin{tabular}{|l|c|c|c|c|}
\hline & Coagulation & $\begin{array}{c}\text { Flocculation } \\
\text { (rapid mixing) }\end{array}$ & $\begin{array}{c}\text { Flocculation } \\
\text { (slow mixing) }\end{array}$ & Settling \\
\hline $\begin{array}{l}\text { Dimensions } \\
(\mathrm{cm})\end{array}$ & $\begin{array}{c}\varnothing=57.5 / \\
\mathrm{h}=104\end{array}$ & $\begin{array}{c}\mathrm{L}=12 / \mathrm{W}=29 / \\
\mathrm{h}=25\end{array}$ & $\begin{array}{c}\mathrm{L}=25.5 / \\
\mathrm{W}=29 / \mathrm{h}=25\end{array}$ & $\begin{array}{c}\mathrm{L}=51 / \\
\mathrm{W}=13.5 / \mathrm{h}=25\end{array}$ \\
\hline Volume (L) & 250 & 7.3 & 15.5 & 15.8 \\
\hline $\begin{array}{l}\text { Detention } \\
\text { time (min) }\end{array}$ & $54.3-107.3$ & $1.6-3.1$ & $3.4-6.6$ & $3.4-6.8$ \\
\hline
\end{tabular}

Table 3: Comparative settled solids volumetric concentrations in an Imhoff cone as a function of time. Conditions: same as figure 4.

\begin{tabular}{|c|c|c|}
\hline & \multicolumn{2}{|c|}{ Volume (mL. $\left.{ }^{-1}\right)$} \\
\hline Time $(\min )$ & PAC & $\mathrm{Fe}^{3+}+$ Starch \\
\hline 5 & 0 & 10 \\
\hline 20 & 5 & 12 \\
\hline 40 & 12 & 13 \\
\hline 60 & 14 & 14 \\
\hline
\end{tabular}

concentration of sludge at $10 \mathrm{~mL} \cdot \mathrm{L}^{-1}$, while the flocs formed with PAC needed almost $40 \mathrm{~min}$ to obtain this very same value. These results match the Flocculation Indexes (FI), obtained by Photometric Dispersion Analysis (PDA), and reveal higher settling kinetics, which is very important in the design of water treatment plants, with a lower footprint. Again, these results are probably due to the denser structure of the flocs generated by ferric chloride plus starch.

Comparative flocculation-settling of kaolin particles: Figure 5 shows the residual turbidity in the treated water as a function of the concentrations of ferric ion (starch concentration kept constant at 10 mg.L $\mathrm{L}^{-1}$ ) with two feed turbidities. Best results were obtained (about 1 NTU or $99 \%$ removal) between $10-15 \mathrm{mg} \cdot \mathrm{L}^{-1} \mathrm{Fe}^{3+}$ and with the higher feed turbidity ( $130 \mathrm{NTU})$, at $\mathrm{pH}=7$. These results of flocculationseparation of the kaolin particles are explained by the following mechanisms:

i. Firstly, rapid adsorption of the starch by a chemical interaction between the amylopectin fraction and the iron present at the surface of the $\mathrm{Fe}(\mathrm{OH})_{3}$ precipitates or flocs $[26,27]$ and, 


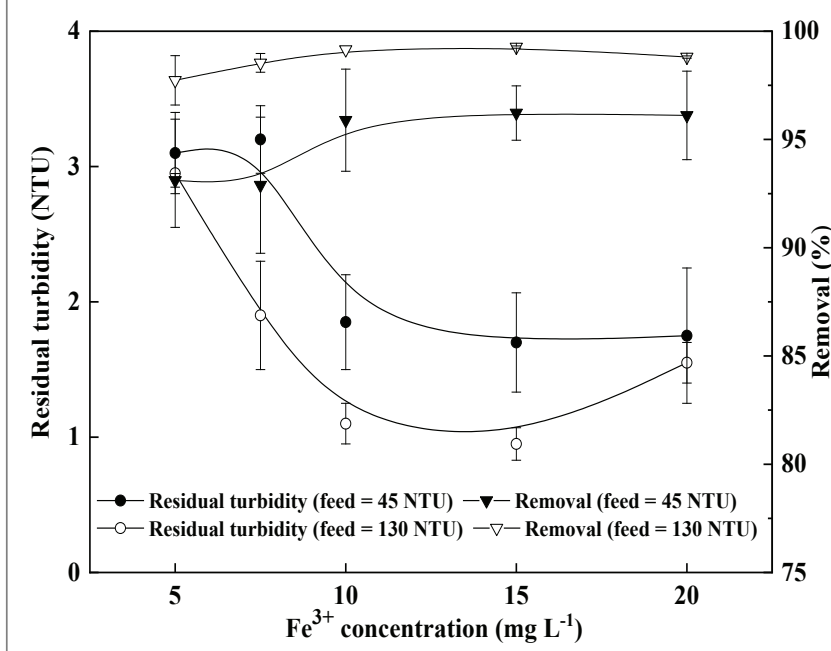

Figure 5: Coagulation-flocculation-settling of kaolin aqueous dispersions. Residual turbidity as a function of the concentration of $\mathrm{Fe}^{3+}$ and feed turbidity ( 45 and 130 NTU or 0.13 and 0.22 g. $\mathrm{L}^{-1}$ of kaolin, respectively). Conditions: [Starch] $=10 \mathrm{mg}^{\mathrm{L}} \mathrm{L}^{-1} ; \mathrm{G}=1000 \mathrm{~s}^{-1}$ (2 min, rapid mixing); $\mathrm{G}=40 \mathrm{~s}^{-1}$ (5 min, slow mixing); settling time $=5 \mathrm{~min}$ and $\mathrm{pH}=7$.

ii. Entrainment or sweeping of the kaolin suspended particles by the flocs as a carrier. The higher the feed turbidity, the more effective is this separation by coagulation-flocculation-settling of kaolin aqueous dispersions.

Figure 6 shows the residual turbidity in the treated water as a function of the concentrations of PAC with a feed turbidity of 45 NTU. The best results (residual turbidity of 1 NTU, 98\% removal) were obtained with $60 \mathrm{mg} . \mathrm{L}^{-1}$ of PAC, employing the same hydrodynamic conditions as those with the iron-starch flocculant $\left(\mathrm{G}=40 \mathrm{~s}^{-1}\right.$ and 5 $\min )$. The turbidity removal was similar to that with $\mathrm{Fe}^{3+}$ and starch, obtained at a higher concentration.

As shown in figure 7 , increasing the velocity gradient $\left(\mathrm{G}, \mathrm{s}^{-1}\right)$ in the slow mixing, from 40 to $100 \mathrm{~s}^{-1}$, with $10 \mathrm{mg} \cdot \mathrm{L}^{-1}$ of $\mathrm{Fe}^{3+}$ plus 7.5 mg. $\mathrm{L}^{-1}$ of starch, gave better results with a removal $>99 \%$ of feed turbidity or residual turbidity of $0.3 \mathrm{NTU}$ (triplicate tests) in the final treated water. Conversely, with PAC, these results were unstable (high standard deviation) and poorer at a velocity gradient higher than 40 $\mathrm{s}^{-1}$ in the slow mixing because the formed flocs were fragile and do not withstand the shear forces. As a result, some of the aggregates were broken and had lower settling velocities and higher residual turbidities. The supplementary data (S) presents further data (effect of $\mathrm{pH}$ and starch concentration).

Coagulation-flocculation-settling studies in a continuous system:

Kaolin suspensions: Figure 8 shows that residual turbidity in the treated water increased as a function of superficial loading by values upto $4 \mathrm{~m} \cdot \mathrm{h}^{-1}$, independent of the reagent used. These results are due to the higher flow velocity (water displacement) and shorter residence time in the separation unit, dragging the flocs towards the treated water outlet. Because of the more turbulent conditions at higher superficial hydraulic loading, some breakage of flocs may occur, decreasing the aggregate settling, keeping them suspended in the treated water.

The presence of inclined lamellae reduced the residual turbidity in the treated water, due to the lower turbulence in the space between

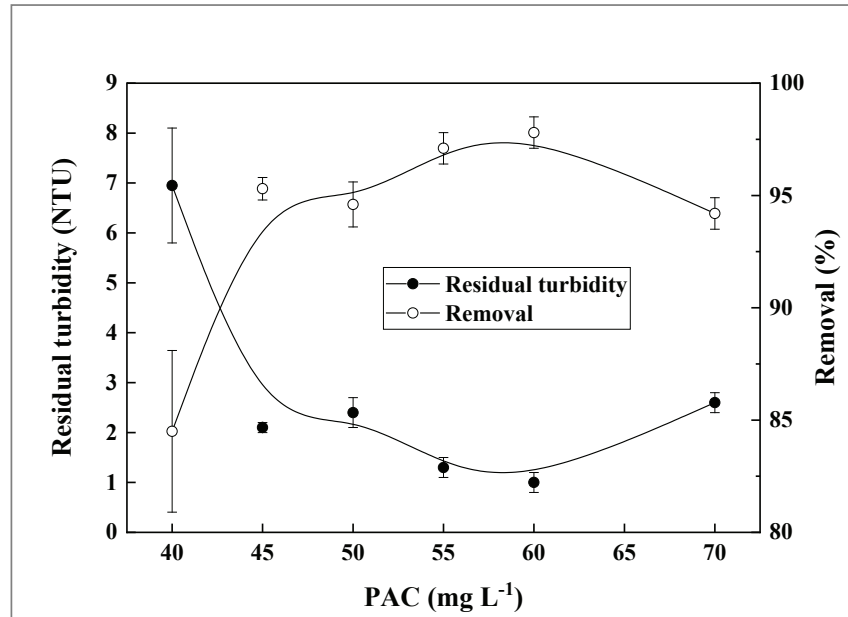

Figure 6: Coagulation-flocculation-settling of kaolin aqueous dispersions at bench scale (jar-test) as a function of the concentration of PAC. Conditions: feed turbidity $=45$ NTU ( $0.13 \mathrm{~g} . \mathrm{L}^{-1}$ of kaolin); $\mathrm{G}=1000 \mathrm{~s}^{-1}$ (2 min, rapid mixing); $\mathrm{G}=40 \mathrm{~s}^{-1}$ (5 min, slow mixing); settling time $=5 \mathrm{~min}$ and $\mathrm{pH}=7.5$.

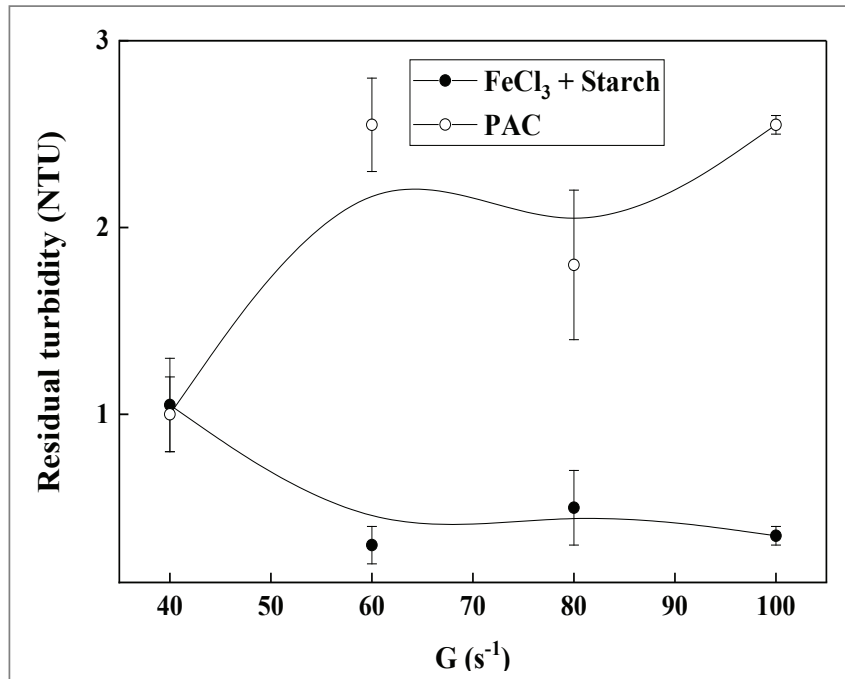

Figure 7: Coagulation-flocculation-settling of kaolin aqueous dispersions at bench scale (jar-test) as a function of the velocity gradient (G), with $\mathrm{FeCl}_{3}$ plus starch or PAC. Conditions: Feed turbidity $=45$ NTU $\left(0.13 \mathrm{~g} . \mathrm{L}^{-1}\right.$ of kaolin); $\left[\mathrm{Fe}^{3+}\right]=10 \mathrm{mg} . \mathrm{L}^{-1}$; $[$ starch $]=7.5$ $\mathrm{mg} \cdot \mathrm{L}^{-1} ; \mathrm{PAC}=60 \mathrm{mg} \cdot \mathrm{L}^{-1}$.

the plates, thus eliminating unstablqe flows and mixing currents. The sloping surfaces of the plates reduce the distance particles need to settle in the bulk suspension, agglomerating and sliding down when they reach the surface of the plates [37-39].

As discussed earlier, the bigger and stronger flocs formed with $\mathrm{Fe}^{3+}$ and starch withstands more shear than those formed with PAC (Figure S6). The faster settling and higher resistance to the shear forces allowed enhancement of the superficial loading in the case of flocculation with starch, reaching values of $3 \mathrm{~m} \cdot \mathrm{h}^{-1}$, keeping the average residual turbidity around 5.6 NTU. 


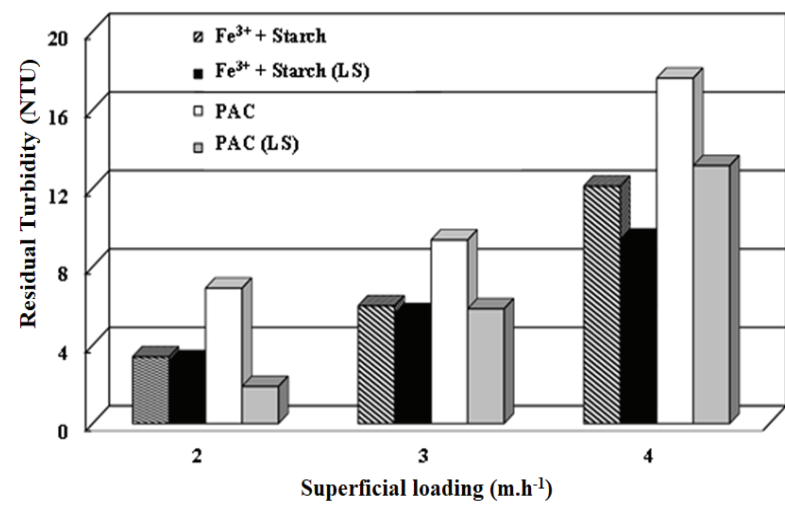

Figure 8: Coagulation-flocculation-settling of kaolin suspended particles in a continuous system.

Residual turbidity (NTU) as a function of the superficial loading, with lamellar settling (LS) and without lamellae. Conditions: Feed

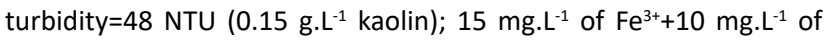
starch; $\mathrm{pH}=7$; G slow mixing $=60 \mathrm{~s}^{-1}$ (starch); $\mathrm{PAC}=60 \mathrm{mg} \cdot \mathrm{L}^{-1} ; \mathrm{pH}=7.5$; G slow mixing $=40 \mathrm{~s}^{-1}$ (PAC).

Public supply raw water: Figure 9 shows excellent results with the combination of $\mathrm{Fe}^{3+}$ plus starch when compared with PAC. The residual turbidity of $2.5 \mathrm{NTU}$, equivalent to a reduction of $90 \%$, was attained at a superficial loading of $3 \mathrm{~m} \cdot \mathrm{h}^{-1}$ using lamellar settling at a higher velocity gradient ( $G$ values, $40 \mathrm{~s}^{-1}$ with PAC and $60 \mathrm{~s}^{-1}$ with $\mathrm{Fe}^{3+}+$ starch).

With a lamellar settling regime, the particles appear to change the floc morphology within the lamellae and, once they have exited these plates, they are not drawn into the treated water liquid flow [39].

The supplementary data (Figures S2 and S3) shows video data of the floc settling and hydrodynamics between the lamellae plates.

These results are considered the most important in this work, because they not only validate the bench and continuous data obtained with kaolin suspensions but also proved higher efficiency showing that with iron chloride and natural starch, higher process (settling) velocities can be obtained. The superficial loading capacity attained is higher than that currently applied at the drinking water treatment plant of COMUSA, which is $2.5 \mathrm{~m} \cdot \mathrm{h}^{-1}$. This enhanced kinetics may bring advantages such as higher loading capacities in settling units with a lower footprint. This research will continue in pilot runs before industrial trials.

\section{Conclusions}

This work shows features on the sustainability of commercial coagulants/flocculants and presents studies on the use of iron chloride and natural starch for coagulation and flocculation in drinking water treatment at bench and continuous scales. Environmental and sanitary (health) aspects of aluminum-based coagulants, polyacrylamides, and tannin reagents were discussed. Experimental results show that a combination of ferric chloride and starch generated well-structured flocs of kaolin (employed as a dispersion model), forming compacted and larger units than those with polyaluminum chloride (PAC), which led to rapid settling. Continuous studies of lamellar settling validated results treating real raw water (Rio dos Sinos, Brazil) and compared the combination of $\mathrm{FeCl}_{3}$ plus starch with PAC. Because of the rapid

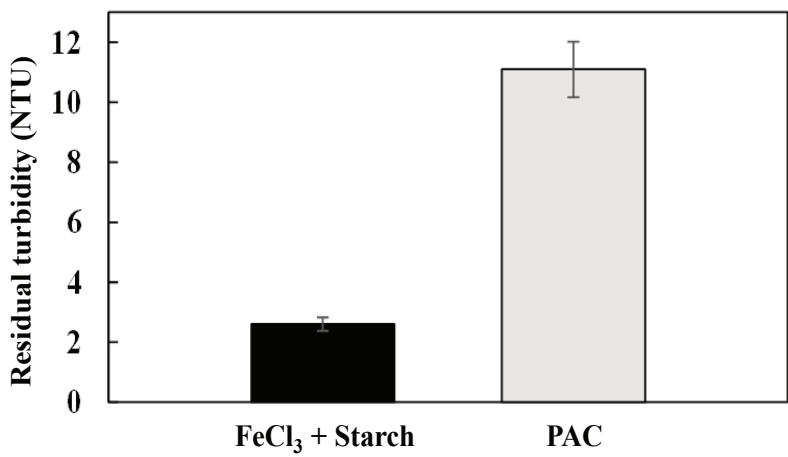

Figure 9: Treatment of raw water from Rio dos Sinos, Brazil in a continuous system of coagulation-flocculation-lamellar settling, using two types of aggregation reagents. Comparison of residual turbidity at a superficial hydraulic loading of $3 \mathrm{~m} \cdot \mathrm{h}^{-1}$. Conditions: initial turbidity $=26 \mathrm{NTU}$; $15 \mathrm{mg} \cdot \mathrm{L}^{-1} \mathrm{Fe}^{3+}+10 \mathrm{mg} \cdot \mathrm{L}^{-1} \mathrm{starch} ; 60 \mathrm{mg} \cdot \mathrm{L}^{-1}$ PAC; $\mathrm{pH}=7 ; \mathrm{G}=40 \mathrm{~s}^{-1}$ (PAC) and $60 \mathrm{~s}^{-1}\left(\mathrm{Fe}^{3+}+\mathrm{starch}\right)$.

settling and higher strength of the flocs formed, best results were obtained with $\mathrm{FeCl}_{3}+$ starch, with a higher velocity gradient $\left(\mathrm{G}, 60 \mathrm{~s}^{-1}\right)$ during slow mixing and with a separation tank with inclined lamellae. The higher turbidity reduction (94\%) with a residual turbidity of 2.5 NTU obtained at a superficial loading of $3 \mathrm{~m} \cdot \mathrm{h}^{-1}$, compared to $58 \%$ of turbidity reduction with PAC (residual turbidity of $11 \mathrm{NTU}$ ), appears to show a good potential of the combination of $\mathrm{FeCl}_{3}$ and starch for solid/liquid separation, especially in drinking water treatment. All results were discussed in terms of interfacial mechanisms involved and operating parameters.

\section{Acknowledgments}

The authors would like to thank all the Brazilian Institutions that supported this study, namely: Comusa-Novo Hamburgo, CNPq (Grant number 421284/2018-8), and UFRGS (EE-FLE-PPGE3M). We would like to give special thanks, for their assistance, to all students of our laboratory-LTM, our technician Alex Rodrigues, friends and former students, Dr. Katia Wilberg and Dr. Ramiro Etchepare.

\section{References}

1. Maćczak P, Kaczmarek H, Ziegler-Borowska M (2020) Recent Achievements in Polymer Bio-Based Flocculants for Water Treatment. Materials 13: 3951.

2. Ang WL, Mohammad AW (2020) State of the art and sustainability of natural coagulants in water and wastewater treatment. J Clean Prod 262: 121267.

3. Bratby J (2016) Coagulation and Flocculation in Water and Wastewater Treatment. $3^{\text {rd }}$ edition, IWA Publishing.

4. BCC Research (2020) Wastewater Treatment: Coagulants, Flocculants, Corrosion Inhibitors, Biocides, and Antifoaming Agents.

5. Bolto B, Gregory J (2007) Organic polyelectrolytes in water treatment. Water Res 41: 2301-2324.

6. Fang G (2007) Evaluation and Performance of a Tannin-based Polymer as a Coagulant in Water Treatment. Imperial College, London, UK. 
7. Ibrahim A, Yaser AZ, Lamaming J (2021) Synthesising tannin-based coagulants for water and wastewater application: A review. J Environ Chem Eng 9: 105007.

8. Machado G, dos Santos CAB, Gomes J, Faria D, Santos F, et al. (2020) Chemical modification of tannins from Acacia mearnsii to produce formaldehyde free flocculant. Sci Total Environ 745: 140875.

9. Rondeau V, Jacqmin-Gadda H, Commenges D, Helmer C, Dartigues JF (2009) Aluminum and Silica in Drinking Water and the Risk of Alzheimer's Disease or Cognitive Decline: Findings From 15-Year Follow-up of the PAQUID Cohort. Am J Epidemiol 169: 489-496.

10. Fekete V, Vandevijvere S, Bolle F, Van Loco J (2013) Estimation of dietary aluminum exposure of the Belgian adult population Evaluation of contribution of food and kitchenware. Food Chem Toxicol 55: 602-608.

11. Klotz K, Weistenhöfer W, Neff F, Hartwig A, Van Thriel C, et al. (2017) The Health Effects of Aluminum Exposure. Dtsch Arztebl Int 114 653-659.

12. United States Environmental Protection Agency (USEPA) (2020) EPA Response to Public Comments on 2017 Draft Aluminum Ambient Water Quality Criteria-EPA-822-R-20-004.

13. World Health Organization (WHO) (2021) Guidelines for drinkingwater quality, $4^{\text {th }}$ edition, incorporating the $1^{\text {st }}$ addendum, 2017

14. Ministério da Saúde (2017) Portaria de Consolidação No 5, de 28 de Setembro de 2017, Annex XX.

15. BMJV (2021) Verordnung über die Qualität von Wasser für den menschlichen Gebrauch (Trinkwasserverordnung-TrinkwV).

16. Health Canada (2019) Aluminum in drinking water: Guideline technical document for consultation.

17. Guezennec AG, Michel C, Bru K, Touze S, Desroche N, et al. (2015) Transfer and degradation of polyacrylamide-based flocculants in hydrosystems: a review. Environ Sci Pollut Res 22: 6390-6406.

18. Xiong B, Loss RD, Shields D, Pawlik T, Hochreiter R, et al. (2018) Polyacrylamide degradation and its implications in environmental systems. Npj Clean Water 1: 1-9.

19. European Comission (2020) Directive (Eu) 2020/2184 of the European Parliament and of the Council of 16 December 2020 on the quality of water intended for human consumption.

20. Beltrán-Heredia J, Sánchez-Martín J, Gómez-Muñoz MC (2010) New coagulant agents from tannin extracts: Preliminary optimisation studies. Chem Eng J 162: 1019-1025.

21. Yin CY (2010) Emerging usage of plant-based coagulants for water and wastewater treatment, Process Biochem 45: 1437-1444.

22. Fraga-Corral $M$, García-Oliveira P, Pereira AG, Lourenço-Lopes $C$, Jimenez-Lopez C, et al. (2020) Technological Application of TanninBased Extracts. Molecules 25: 614.

23. American National Standards Institute (ANSI) (2017) NSF/ANS 60-2017-Drinking water treatment chemicals-Health effects.

24. Pavlovic S, Brandao PR (2003) Adsorption of starch, amylose, amylopectin and glucose monomer and their effect on the flotation of hematite and quartz. Miner Eng 16: 1117-1122.
25. Weisseborn PK, Warren LJ, Dunn JG (1995) Selective flocculation of ultrafine iron ore. 1. Mechanism of adsorption of starch onto hematite. Colloids Surfaces A Physicochem Eng Asp 99: 11-27.

26. Oliveira HA, Azevedo A, Rubio J (2019) Innovative PrecipitationFlocculation Process for Treating Turbid Waters from Gualaxo do Norte River, Brazil. Mining Metall Explor 36: 851-856.

27. Oliveira HA, Azevedo A, Rubio J (2021) Removal of flocculated $\mathrm{TiO}_{2}$ nanoparticles by settling or dissolved air flotation. Environ Technol 42: 1001-1012.

28. Solodovnik TV, Kultenko VS, Slis AA (2020) Research on the efficiency of use of natural polymer flocculants in the process of water solution purification. Вісник Черкаського державного технологічного університету 1: 50-56.

29. Lima Júnior RN, Abreu FOMS (2018) Produtos Naturais Utilizados como Coagulantes e Floculantes para Tratamento de Aguas: Uma Revisao sobre Benefícios e Potencialidades. Rev Virtual Quim 10: 709-735.

30. Asharuddin SM, Othman N, Zin NSM, Tajarudin HA, Md Din MF (2019) Flocculation and antibacterial performance of dual coagulant system of modified cassava peel starch and alum. J Water Process Eng 31: 100888.

31. Teh CY, Wu TY, Juan JC (2014) Potential use of rice starch in coagulation-flocculation process of agro-industrial wastewater: Treatment performance and flocs characterization. Ecol Eng 71: 509-519.

32. Gregory J, Nelson DW (1986) Monitoring of aggregates in flowing suspensions. Colloids and Surfaces 18: 175-188.

33. Baird RB, Eaton AD, Franson MAH (2017) American Public Health Association, American Water Works Association. Eaton AD, Rice EW, Bridgewater L, Baird R, Water Environment Federation (eds) Standard Methods for the Examination of Water and Wastewater $23^{\text {rd }}$ edition, American Public Health Association.

34. Filippov LO, Severov VV, Filippova IV (2013) Mechanism of starch adsorption on Fe-Mg-Al-bearing amphiboles. Int J Miner Process 123: $120-128$

35. Abdo SM, Mahmoud RH, Youssef M, El-Naggar ME (2020) Cationic Starch and Polyaluminum Chloride as Coagulants for River Nile Water Treatment. Groundw Sustain Dev 10: 100331.

36. Ren J, Li N, Wei H, Li A, Yang H (2020) Efficient removal of phosphorus from turbid water using chemical sedimentation by $\mathrm{FeCl}_{3}$ in conjunction with a starch-based flocculant. Water Res 170: 115361

37. Duan J, Gregory J (2003) Coagulation by hydrolysing metal salts. Adv Colloid Interface Sci 100-102: 475-502

38. Silva R, Cadorin L, Rubio J (2010) Sulphate ions removal from an aqueous solution: I. Co-precipitation with hydrolysed aluminumbearing salts. Miner Eng 23: 1220-1226.

39. Tarpagkou R, Pantokratoras A (2014) The influence of lamellar settler in sedimentation tanks for potable water treatment-A computational fluid dynamic study. Powder Technol 268: 139-149. 


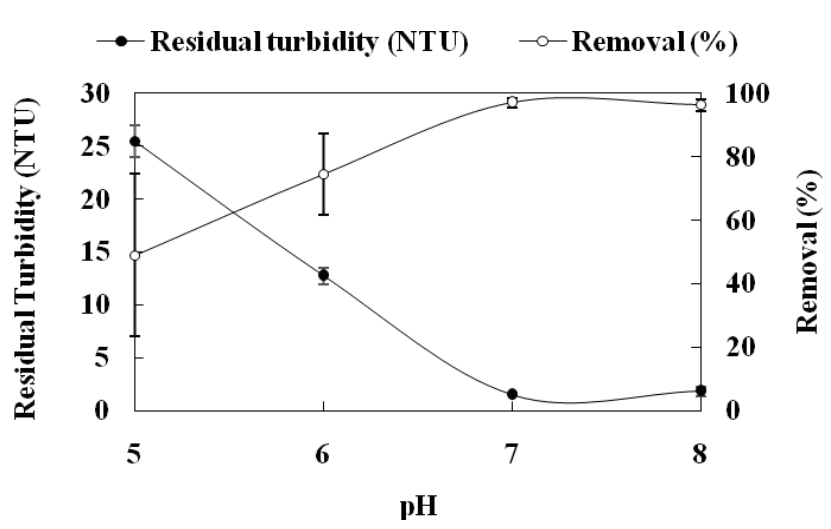

Figure S1: Coagulation-flocculation-settling of kaolin aqueous dispersions at bench scale (jar-test), as a function of $\mathrm{pH}$. Conditions: feed turbidity=50 NTU (0.15 g. $\mathrm{L}^{-1}$ of kaolin); [ $\left.\mathrm{Fe}^{3+}\right]=10 \mathrm{mg} \cdot \mathrm{L}^{-1} ; \mathrm{G}=1000 \mathrm{~s}^{-1}$ ( $2 \mathrm{~min}$, rapid mixing); [starch]=10 mg. $\mathrm{L}^{-1} ; \mathrm{G}=50 \mathrm{~s}^{-1}$ (5 min, slow mixing); settling time=5 min.

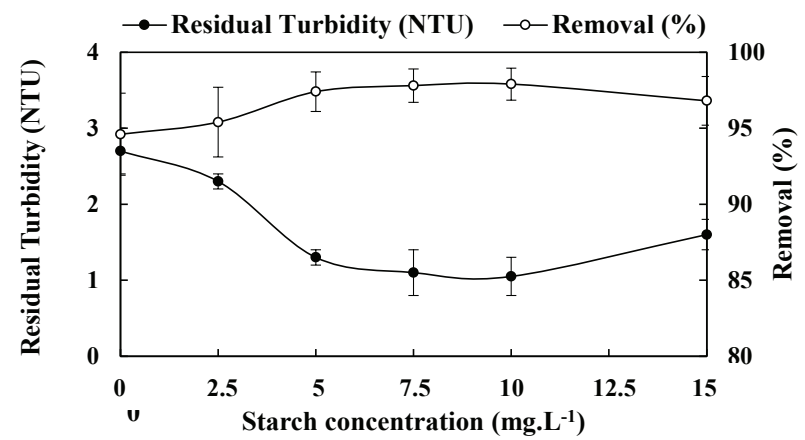

Figure S2: Coagulation-flocculation-settling of kaolin aqueous dispersions at bench scale (jar-test) as a function of the concentration of starch. Conditions: feed turbidity $=50$ NTU (0.15 g. $\mathrm{L}^{-1}$ of kaolin); $\left[\mathrm{Fe}^{3+}\right]=10 \mathrm{mg} \cdot \mathrm{L}^{-1} ; \mathrm{G}=1000 \mathrm{~s}^{-1}$ ( $2 \mathrm{~min}$, rapid mixing); G=70s ${ }^{-1}$ (5 min, slow mixing); settling time $=5 \mathrm{~min}$ and $\mathrm{pH}=7$.

Microphotographs of flocs formed with $\mathrm{Fe}^{3+}+$ gelatinized starch
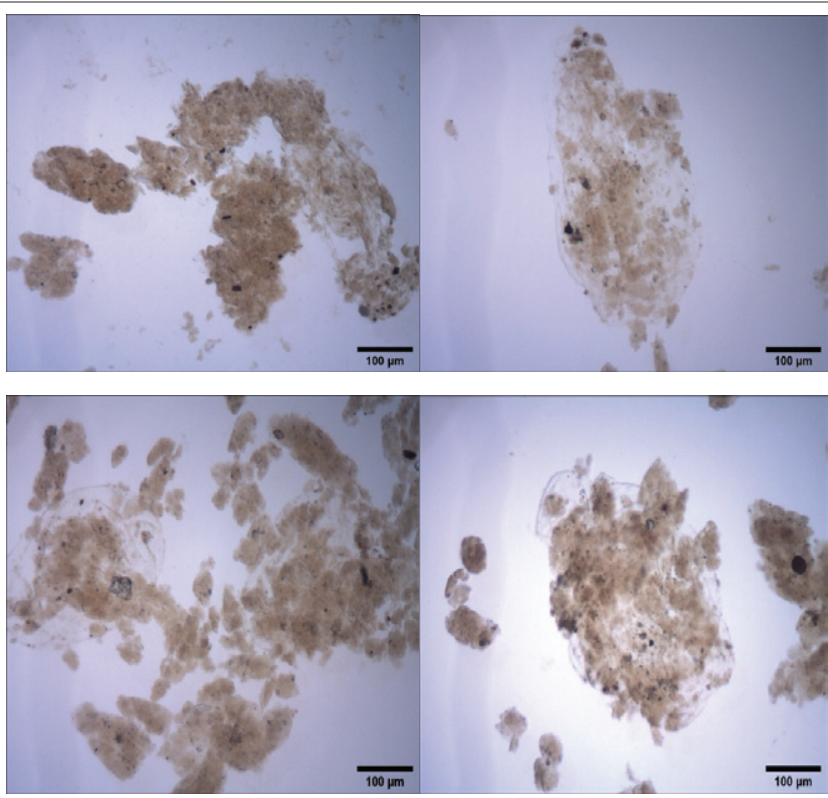

Figure S3: Coagulation-flocculation of raw water (Rio dos Sinos, Brazil) at bench scale. Microphotographs (1280 $\times 1024$ pixels) of flocs formed with $\mathrm{Fe}^{3+}+$ starch. Conditions: Feed turbidity $=33.2 \mathrm{NTU} ; 15 \mathrm{mg} \cdot \mathrm{L}^{-1} \mathrm{Fe}^{3+}+10 \mathrm{mg} \cdot \mathrm{L}^{-1}$; rapid mixing G of $1000 \mathrm{~s}^{-1} / 2 \mathrm{~min}$; slow mixing G=60 s-1/5min and pH=7. 
Microphotographs of flocs

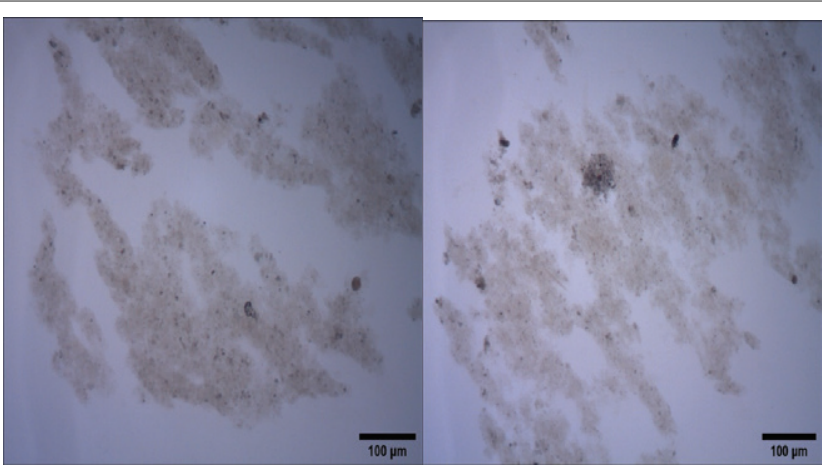
formed with PAC

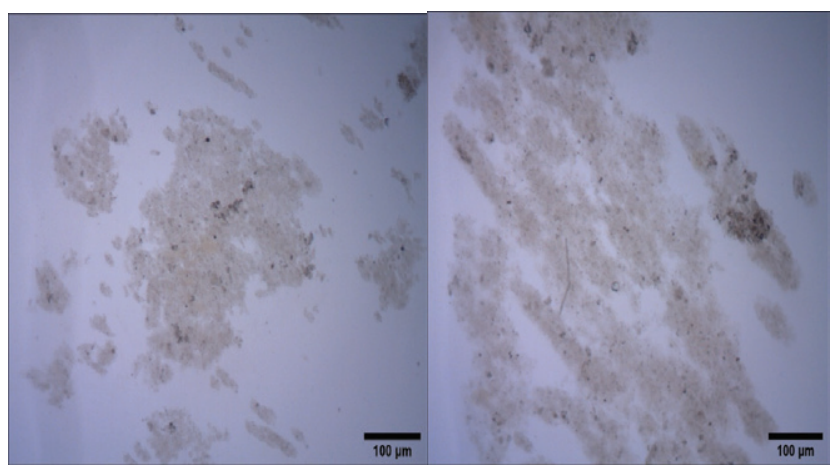

Figure S4: Coagulation-flocculation of raw water (Rio dos Sinos, Brazil) at bench scale. Microphotographs $(1280 \times 1024$ pixels) of flocs formed with PAC. Conditions: Feed turbidity=33.2 NTU; $60 \mathrm{mg}^{-L^{-1}}$ of PAC; rapid mixing (PAC) $=\mathrm{G}$ of $1000 \mathrm{~s}^{-1} / 2 \mathrm{~min}$; slow mixing G=40 s-1/5 min and pH=7.
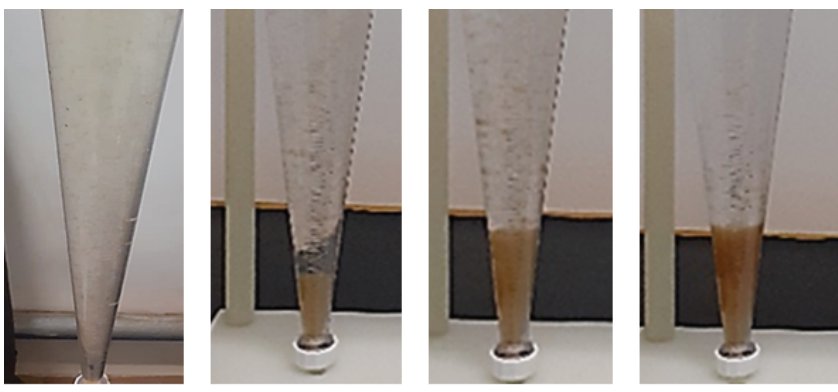

\section{PAC}

$60 \mathrm{mg} . \mathrm{L}^{-1}$

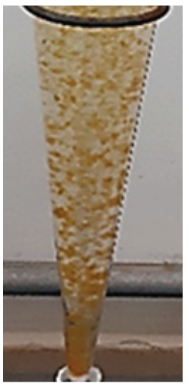

$1 \mathrm{~min}$

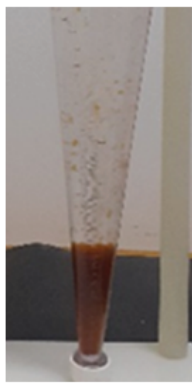

$15 \min$

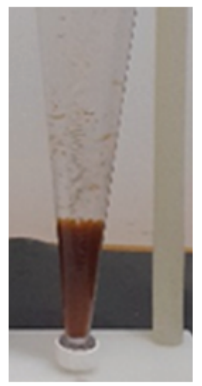

$30 \mathrm{~min}$

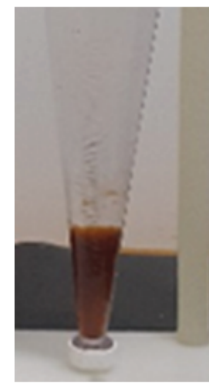

$60 \mathrm{~min}$

\section{$\mathrm{Fe}^{3+}+$ starch}

$15 \mathrm{mg} . \mathrm{L}^{-1}+10 \mathrm{mg} \cdot \mathrm{L}^{-1}$

Figure S5: Imhoff cone assays for the characterization of the volume of settled flocs, with PAC (60 mg. $\left.\mathrm{L}^{-1}\right)$ and Fe $\mathrm{F}^{3+}$ plus starch $\left(15 \mathrm{mg} \cdot \mathrm{L}^{-1}+10\right.$ mg. $\left.L^{-1}\right)$. 


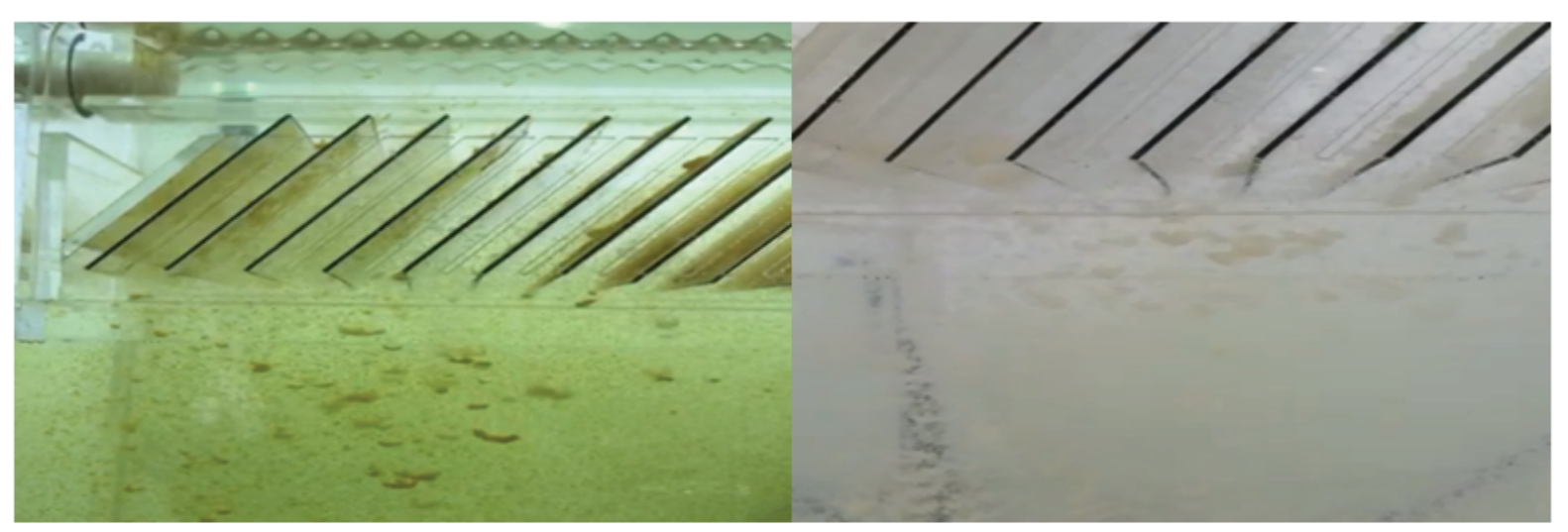

a

$\mathrm{b}$

Figure S6: Kaolin flocs settling in the continuous system. a) $\mathrm{Fe}^{3+}\left(15 \mathrm{mg} \cdot \mathrm{L}^{-1}\right)+\mathrm{starch}\left(10 \mathrm{mg} \cdot \mathrm{L}^{-1}\right), \mathrm{pH}=7, \mathrm{G}$ slow mixing=60s $\left.\mathrm{s}^{-1} ; \mathrm{b}\right) \mathrm{PAC}\left(60 \mathrm{mg} \cdot \mathrm{L}^{-1}\right)$, $\mathrm{pH}=7.5$, G slow mixing $=40 \mathrm{~s}^{-1}$. Both conditions with initial turbidity=48 NTU ( $0.15 \mathrm{~g} \cdot \mathrm{L}^{-1}$ of kaolin) and superficial loading $=2 \mathrm{~m} \cdot \mathrm{h}^{-1}$.

Full video link: https://youtu.be/iMeebuEgeSE 